\title{
Mengukur Kompetensi Amil Melalui Kemampuan Menajerial dan Profesionalitas di Lembaga Zakat Nurul Hayat Surabaya
}

\author{
Hanafi Adi Putranto \\ UIN Sunan Ampel Surabaya \\ hanafiadiputranto@uinsby.ac.id \\ Siti Nur Azizah \\ UIN Sunan Ampel Surabaya \\ sitiazizah@gmail.com
}

\begin{abstract}
Abstrak
Penelitian ini bertujuan untuk mengukur tingkat kompetensi amil zakat dari aspek perorangan sebagai potensi sumber daya manusia yang ada di lembaga zakat. Penelitian ini penting dilakukan, mengingat banyaknya isu yang beredar tentang eksistensi amil zakat yang kurang profesional dan inovatif dalam melakukan aktivitas manajemen, selain itu, juga gencarnya pemerintah melakukan sertifikasi amil untuk perbaikan pengelolaan zakat. Signifikansi penelitian ini terletak pada uji pengukuran yang dilakukan oleh peneliti, yaitu mangambil variabel pola manajerial dan kemampuan bersikap, berpikir dan melakukan profesionalisme dalam tugas pengelolaan. Penelitian ini dilakukan di lembaga amil zakat Nurul Hayat Surabaya, pemilihan lokasi ini sebagai manifestasi dari lembaga amil zakat lainnya karena Lembaga Zakat Nurul Hayat Surabaya memiliki cabang di beberapa kabupaten. Metode penelitian yang digunakan adalah pendekatan kualitatif deskriptif. Dalam metode pengumpulan data dilakukan dengan cara observasi, wawancara dan dokumentasi. Wawancara dilakukan secara langsung kepada manajer penghimpunan, ketua fundraising, direktur pendayagunaan, manajer pendistribusian dan manajer pendayagunaan. Setelah dilakukan penelitian, didapatkan hasil yaitu amil zakat di Nurul Hayat Surabaya telah memiliki kemampuan dan profesionalisme dalam pengelolaan zakat. Kemampuan amil dalam mengelola zakat dapat diketahui melalui training, pengalaman dalam bidang pekerjaan dan pencapaian target setiap amil. Profesionalisme amil dalam mengelola zakat dapat diketahui melalui tanggung jawab, komitmen dan keinginan amil untuk meningkatkan kemampuan. Adapun upaya dari lembaga untuk meningkatkan kemampuan amilnya adalah dengan dilakukan evaluasi untuk mengetahui kebutuhan dalam meningkatkan kemampuan amil, kemudian diberikan training.
\end{abstract}

Keyword : Kemampuan, Profesionalisme, Amil, Pengelolaan Zakat 
MAZAWA: Manajement of Zakah and Waqf Volume 1, Nomor 1 Desember 2019

\section{Latar Belakang}

Dalam dekade terakhir, komptensi amil pada lembaga zakat mulai disorot. Tentu sorotan ini bukan tanpa alasan, berbagai kelemahan amil terlihat manakala lembaga zakat tidak mampu memenuhi harapan masyarakat dan negara. Potensi dana zakat yang sangat tinggi, tidak dibarengi oleh hasil yang didapat atau setidaknya "mendekati"; zakat lebih banyak menerapkan model pengelolaan zakat klasik di mana pengelolaan bersifat chirity; dan, lembaga zakat belum mampu menerapkan zakat sebagai tonggak perekonomian masyarakat. ${ }^{1}$

Problem ini menjadi semakin akut ketika banyak ditemukan masalah internal lain yang tidak seirama dengan aturan yang ada. Menurut penelitian, amil di lembaga zakat sama sekali tidak kompetitit dan profesional. ${ }^{2}$ Fakta ini dapat dilihat dari pola perekrutan amil yang tidak memandang kesarjanaan, bersistem semua rumpun keilmuan dan penilaian kompetensi lebih bersifat instan. ${ }^{3}$ Hal ini masih berjalan sampai sekarang dan belum ada solusi mapan untuk menyelesaikannya. Belum lagi ditambah oleh kelembagaan zakat yang menuai problem seperti eksistensi lembaga zakat swasta dan negeri. ${ }^{4}$

Kedua problem internal dan eksternal ini, membuat pemerintah berencana untuk -secara gradual- melakukan perbaikan dimulai dari sisi kompetensi amil. Perbaikan ini dapat tercapai melalui program sertifikasi amil. Untuk yang telah menjabat sebagai amil, maka diberikan pelatihan khusus sedangkan bagi calon amil diberikan pelatihan sangat ketat untuk menjadi amil profesional. Hal ini dibenarkan oleh Luis Fatmawati bahwa problem pertama yang harus dibenahi adalah membenahi kompetensi amil sebagai roda penggerak lembaga zakat.

Pengelolaan zakat sendiri adalah kegiatan perencanaan, pelaksanaan dan pengoordinasian dalam pengumpulan, pendistribusian dan pendayagunaan

\footnotetext{
${ }^{1}$ Oni Sahroni, Figh Zakat Kontemporer. Depok: PT Raja Grafindo Persada, 2018, hlm. 265.

2 Lusi Fatmawati, Pengaruh Shariah Compliance, Transaparansi, Akuntabilitas dan Kompetensi Sumber Daya Manusia (SDM) Terhadap Pengelolaan Dana Zakat (Studi pada Organisasi Pengelola Zakat di Kabupaten Sukoharjo), Skripsi, Institut Agama Islam Negeri Surakarta tahun 2017, hlm. 80.

${ }^{3}$ Misti Hariasih, Herlina Maya Kumala Sari dan Totok Dwi Prasetyo, Pengaruh Penilaian Prestasi Kerja, Kompetensi Karyawan dan Pengalaman Kerja terhadap Promosi Jabatan pada Lembaga Amil Zakat Nasional Nurul Hayat Surabaya. Jurnal Bisnis Manajemen dan Perbankan, 3 (2) 2017, hlm. 139.

${ }^{4}$ M. Yudistira Kusuma, "Respon Pengurus Forum Organisasi Zakat terhadap Undang-Undang No. 23 Tahun 2011 tentang Pengelolaan Zakat", Skripsi UIN Jakarta (2013), hlm. 40.
} 
Hanafi Adi Purwanto, Mengukur Kompetensi Amil Melalui Kemampuan...

zakat. ${ }^{5}$ Peran lembaga amil zakat dan badan amil zakat dalam pegelolaan zakat secara konsep memiliki beberapa tugas; pertama melakukan pendataan muzakki (golongan yang wajib membayar zakat) dan mustahik (golongan yang wajib menerima zakat), melakukan pembinaan mustahik dalam rangka memaksimalkan penyaluran zakat, mengumpulkan dan menjemput zakat dari muzakki dan mendoakan muzakki, kemudian menyusun administratif dan manajerial seperti pencatatan dari data yang terkumpul tersebut. Kedua, memanfaatkan data yang terkumpul untuk membuat rencana anggaran kebutuhannya dan menentukan bentuk pendistribusian dan pemberdayaan yang diperlukan. ${ }^{6}$

Lembaga atau organisasi zakat jika dikelola oleh amil yang amanah dan jujur, akan berdampak pada kepercayaan muzakki. Salah satu alasan muzakki dalam membayarkan zakat pada suatu lembaga adalah pengelolaan yang baik. ${ }^{7}$ Zakat yang tidak dikelola dengan baik, akan berakibat pada hilangnya kepercayaan Muzakki terhadap lembaga amil zakat. Sebagaimana telah terjadi penyelewengan dana zakat infaq dan shodaqoh di Aceh. ${ }^{8}$ Kepercayaan muzaki memegang peranan penting dari penghimpunan dana zakat, ketika muzaki sudah mempercayai suatu lembaga untuk mengelola zakatnya, maka ia akan terus membayarkan dana zakat kepada lembaga amil zakat tersebut. ${ }^{9}$ Untuk itu penting adanya menjaga dan menumbuhkan kepercayaan muzaki dengan dilakukannya pengelolaan zakat yang profesional .

Untuk dana zakat yang dikelola dengan profesional memerlukan kemampuan yang dimiliki seorang karyawan dalam menyelesaikan pekerjaan. Kemampuan adalah salah satu indikator bahwasanya karyawan tersebut telah profesional dalam melaksanakan perkerjaanya. Seseorang dikatakan profesional jika memenuhi tiga kriteria, yaitu memiliki keahlian atau kemampuan untuk melaksanakan tugas sesuai dengan bidangnya, melaksanakan tugas atau profesi dengan menetapkan standart baku di bidang

\footnotetext{
${ }^{5}$ Undang-undang No. 23 tahun 2011, Tentang Pengelolaan Zakat, pasal 1.

${ }^{6}$ M. Arief Mufraini, Akuntansi dan Manajemen Zakat, (Jakarta : Kencana 2006), hal. 195.

7 Didin Hafidhuddin, Zakat dalam Perekonomian Modern, (Jakarta : GEMA INSANI.2002), hal. 127.

8Hasyim, http://aceh.tribunnews.com/amp/2014/01/08/kepala-baitul-mal-tersangkapenyelewengan-dana-zakat, diakses pada 08 Desember 2018.

9 Anim Nasim, Muhammad Rizqi Syahri Romdhon, "Pengaruh Transparansi Keuangan Zakat, Sikap Pengelola Zakat Terhadap Tingkat Kepercayaan Muzakki", Jurnal Riset Akuntansi dan Keuangan, Vol 2, (Th. 2014), hal. 550.
} 
profesi yang bersangkutan dan menjalankan profesinya dengan memenuhi etika profesional yang bersangkutan. ${ }^{10}$

Lembaga zakat Nurul Hayat Surabaya adalah lembaga pengelolaan zakat, infak, dan shadaqoh. Lembaga yang dua tahun berturut - turut mendapat penghargaan sebagai LAZNAS penghimpunan terbaik 2017 dan baru-baru ini mendapatkan penghargaan sebagai LAZNAS (Lembaga Amil Zakat Nasional) terbaik di BAZNAS AWARDS. ${ }^{11}$ BAZNAS Awards ditujukan sebagai wujud apresiasi pelaksanaan pengelolaan zakat. Acara ini diharapkan mampu mendorong lembaga pengelola zakat dalam mewujudkan pengelolaan zakat yang optimal.

Untuk mewujudkan pengelolaan zakat yang optimal, perlu adanya peran aktif dari amil yang memiliki kemampuan dan profesionalisme dalam mengembangkan dan mengupayakan pengelolaan zakat secara profesional, supaya pemanfaatan zakat mampu dirasakan seluas-luasnya oleh orang yang berhak menerima zakat. Untuk mendapatkan amil yang memiliki kemampuan dan profesionalisme, Lembaga Amil Zakat Nurul Hayat Surabaya perlu melaksanakan perekrutan calon amil dengan kualifikasi amil yang dibutuhkan dalam pengelolaan zakat.

Dalam hal ini menarik peneliti untuk mengetahui secara mendalam kemampuan dan profesionalisme amil di Nurul Hayat Surabaya. Amil yang secara personal memiliki peran penting dalam pelaksanaan pengelolaan zakat, yang diharapkan mampu mengupayakan pengembangan kualitas pengelolaan ditengah kebutuhan masyarakat akan amil dan tergerusnya kepercayaan muzakki terhadap pengelolaan zakat, bagaimana bentuk dari kemampuan dan profesionalisme amil dalam pengelolaan zakat dan pengembangan kemampuan dan profesionalisme amil yang ada di lembaga Nurul Hayat Surabaya.

10 Lailatul Fujianti,"Pengauh Profesionalisme Terhadap Komitmen Organisasi Da Kepuasan Kerja Serta Dampaknya Terhadap Kinerja Akuntan Pendidik", Forum Bisnis Dan Keuagan (Th. 2012), hal. 818.

11 Arif Prasetyo,"Inilah Para Juara BAZNAS AWARD 2018" , http://www.gatra.com/rubik/ekonomi/343401, diakses pada 4 Desember 2018. 
Hanafi Adi Purwanto, Mengukur Kompetensi Amil Melalui Kemampuan...

\section{Kerangka Teoritis}

\section{Amil dan Manajemen}

Amil adalah semua pihak yang melakukan pekerjaan berupa pengumpulan, penyimpanan, pencatatan, pengawasan dan penyaluran harta zakat. ${ }^{12}$ Amil menurut konsep kajian fiqih adalah orang atau lembaga yang memiliki tugas untuk memungut, menggambil dan menerima zakat dari para muzakki, menjaga dan memeliharanya, kemudian menyalurkan zakat tersebut kepada mustahik. ${ }^{13}$ Jadi, yang dimaksud sebagai amil adalah pihak yang terlibat dalam pengelolaan zakat, yaitu penghimpunan, pendistribusian dan pendayagunaan zakat. Amil memiliki tugas dan wewenang yang penting dalam pengelolaan zakat di suatu lembaga. Peran penting amil dalam pengelolaan zakat berdampak pada kesejahteraan yang mampu diciptakan amil dalam memaksimalkan pemanfataan zakat.

Keith Davis, yang merumuskan bahwa : ${ }^{14}$ Kemampuan atau ability terdiri dari Knowledge (pengetahuan) dan Skill (ketrampilan). Teori Sutermeister menyatakan bahwa kemampuan berasal dari pengetahuan dan keterampilan, pengetahuan dipengaruhi oleh pengalaman, pelatihan dan minat yang ada pada seseorang sedangkan keterampilan dipengaruhi oleh kepribadian, pendidikan, pengalaman dan minat. Kemampuan menekankan pengertian sebagai hasil dari apa yang telah dilaksanakan oleh karyawan dan kontribusi mereka terhadap perusahaan. ${ }^{15}$

Pengetahuan adalah hasil untuk mengetahui sesuatu oleh seseorang yang didapatkan melalui proses mengamati, mengingat, menyangka dan menalar. ${ }^{16}$ Skill atau ketrampilan adalah bakat yang dipelajari yang dimiliki oleh seseorang untuk melaksanakan tugas. ${ }^{17}$ Kemampuan yang harus dimiliki amil untuk mewujudkan tujuan undang-undang yaitu :

12 Syaikh Muhammad Abdul Malik Ar-Rahman, Pustaka Cerdas Zakat : 1001 Masalah dan Solusinya, (Jakarta : Lintas Pustaka.2003), hal. 181.

${ }^{13}$ M. Arief Mufraini, Akuntansi Manajemen Zakat, (Jakarta : Kencana Prenada Media Group. 2006), hal. 194.

14 Anwar Prabu Magkunegara,Manajemen Sumber Daya Manusia Perusahaan, (Badung : PT Rosdakarya, 2013), hal. 67

${ }^{15}$ Hanani Fauziatunisa, dkk, Analisis Kemampuan Kerja, Coaching dan Kinerja Karyawan : Studi Kasus Pada Karyawan PT Sari Ater Hotel Dan Resort Subang, Jurnal Of Business Management Education,Vol. 3, No. 3, (Oktober 2018), hal. 59

${ }^{16}$ Tri Esti Budiman dan Imam Firmansyah, Efektivitas Pelatihan Public Speaking Terhadap Peningkatan Pengetahuan Tentang Komunikasi Pada Fasilitator Experience Learning (Outbound) PT Hucle Consulting. INTUISI Jurnal Psikologi Ilmiyah, (Juli, 2012),hal. 57

${ }^{17}$ John M. Ivancevich, dkk, Perilaku dan Organisasi 1, (Jakarta: ERLANGA. 2006), hal. 85 
a. Paham Ilmu Fiqih Zakat

Agar organisasi zakat bisa berjalan dengan baik, lembaga tersebut harus didukung dengan adanya sumber daya manusia yang memiliki kualifikasi kemampuan, yang harus dimiliki, salah satunya adalah paham mengenai ilmu fiqih zakat. ${ }^{18}$ Dalam hal ini yang berkaitan dengan ilmu fiqih zakat adalah pengetahuan dan pemahaman tentang muzakki, peritungan zakat, mustahik, haul, nishab, hukum - hukum zakat dan macam-macam zakat.

b. Kemampuan Pemasaran

Pemasaran adalah suatu proses yang didalamnya terdapat individu dan kelompok yang mendapatkan keinginannya dengan cara menciptakan, menawarkan, dan mempertukarkan produk yang bernilai pada pihak lain. ${ }^{19}$

c. Kemampuan Public Speaking

Public Speaking yang dikemukakan oleh Hardiansyah (2003) adalah keterampilan yang dapat dilatih, dipraktikan dan dimanfaatkan sesuai dengan kebutuhan audien, antara lain untuk menyampaikan informasi, memotivasi, membujuk dan mempengaruhi orang lain, meraih promosi jabatan, mengarahkan para kerja/staf, meningkatkan penjualan produk, dan membagikan pengetahuan yang dimiliki. ${ }^{20}$

\section{Profesionalisme Amil}

Profesesionalisme merupakan kecenderungan sikap, mental atau tindakan anggota dalam menjalankan tugas profesinya. Profesionalisme juga dapat diartikan sebagai komitmen seseorang atau anggota suatu profesi untuk menjalankan tugas dan fungsinya. ${ }^{21}$ Komitmen adalah suatu sikap seseoarang yang mencerminkan sikap loyalitas terhadap suatu lembaga dan merupakan proses yang sedang berjalan peserta organisasi atau lembaga menyataka perhatian mereka terhadap organisasi, kelanjutan keberhasilan dan kesejahteraan. $^{22}$

Pengelolaan zakat adalah kegiatan perencanaan, pelaksanaan, dan pengorganisasian dalam pengumpulan, pendistribusian dan pendayagunaan

\footnotetext{
${ }^{18}$ Umrotul Khasanah, Manajemen Zakat Modern,(Malang: UIN MALIKI PRESS.2010)hal. 71

19 Nandan Limakrisna dan Wilhelmus Hary Susilo, Manajemen Pemasaran, (Jakarta: Mitra Wacana Media.2012),hal.3

${ }^{20}$ Irwani Pane, Analisis kemampuan Public Speaking anggota DPRD kota Makassar Masa Bakti 2009-2014, Jurnal Komunikasi KAREBA, Vol. 1 No. 1, ( Jauari - Maret,2011 ),hal. 47.

${ }^{21}$ Ibid.,28.

${ }^{22}$ Wibowo, Perilaku dalam Organisasi, (Jakarta : Pt Raja Grafindo Persada.2016), hal.
} 
Hanafi Adi Purwanto, Mengukur Kompetensi Amil Melalui Kemampuan...

zakat. ${ }^{23}$ Pertama, penghimpunan. Penghimpunan adalah pengumpulan dana zakat dari orang kaya yang telah memenuhi syarat untuk membayar zakat. Kedua, pendistribusian. Pelaksanaan distribusi zakat memiliki sasaran dan tujuan. Sasaran dari pendistribusian zakat adalah pihak-pihak yang diperbolehkan menerima zakat. Sedangkan tujuannya adalah sesuatu yang dapat dicapai dari alokasi dana zakat dalam rangka sosial ekonomi, yaitu meningkatkan kesejahteraan masyarakat dalam bidang perekonomian sehingga dapat memperkecil kelompok masyarakat miskin. Yang pada akhirnya mampu meningkatkan jumlah muzakki. ${ }^{24}$ Ketiga, pendayagunaan. Secara umum terdapat dua pendapat tentang pendayagunaan dana zakat. Pertama, Bahwa zakat lebih bersifat konsumtif dan penyalurannya langsung diserahkan pada pihak yang berhak menerima dana zakat (delapan golongan). Kedua, bahwa pendayagunaan dana zakat mengandung aspek sosial ekonomi yang sangat luas tidak sekedar konsumtif. ${ }^{25}$

\section{Metode Penelitian}

Metode yang digunakan adalah metode kualitatif dengan teknik analisis data deskriptif analisis. Diskriptif analisis adalah pemaparan secara umum dari data - data yang dihimpun berdasarkan observasi dan pada pertanyaanpertanyaan yang bersifat umum yang diajukan kepada amil Nurul Hayat Surabaya, dan menganalisis hasil observasi dan pernyataan dari partisipan dengan didiskripsikan kemudian diklasifikasikan atau disimpulkan menjadi beberapa katagori data atau ciri-ciri dari katagori data, kemudian dianalisis dan disimpulkan secara umum. Proses analisis data secara keseluruhan melibatkan usaha memaknai data yang berupa teks maupun gambar. ${ }^{26}$

\section{Hasil dan Pembahasan \\ Kemampuan Fundraising}

Fundraising atau penghimpunan adalah kegiatan mencari calon donatur atau calon muzakki untuk melaksanakan kewajiban sebagai umat Islam, yaitu membayar zakat. Untuk memahami fiqih zakat, amil Nurul Hayat melakukan

\footnotetext{
${ }^{23}$ Undang -Undang No. 23 Tahun 2011 Tentang Pengelolaan Zakat, Pasal 1.

${ }^{24}$ Ibid.,170-173

25 Muhammad dan Ridwan Mas'ud, Zakat dan Kemiskinan,( YOGYAKARTA : UII PRESS.2005)hal. 102.

${ }^{26}$ John W. Creswell, Research Design Pendekatan Kualitatif, Kuantitatif, dan Mixed, Achmad Fawaid, (Yogyakarta :PUSTAKA PELAJAR.2010), hal. 274.
} 
training atau pelatihan yang diadakan kantor maupun luar kantor dan kemampuan tersebut juga dapat dilihat dari pengalaman amil dalam melaksanakan tugas dan tanggung jawab pekerjaan. Sebelum pelaksaan training dilakukan pihak manajemen melakukan evaluasi dengan cara melihat pencapaian target yang telah ditentukan. Training yang diikuti oleh amil adalah fiqih zakat, dan Fundraising.

Kemampuan lain yang harus dimiliki oleh amil adalah Public Speaking, kemampuan ini ada pada diri amil di Nurul Hayat Surabaya dilihat dari target yang mampu dihimpun oleh amil. Kemampuan Public Speaking adalah Mempengaruhi muzakki untuk membayar zakat atas kewajiban yang sudah jatuh kepadanya, adalah salah satu strategi yang menjadi tujuan pentingnya kemampuan public speaking untuk amil. Semakin amil menguasai keahlian public speaking tidak menutup kemungkinan perolehan penghimpunan akan berbanding lurus dengan kemampuan

Kemudian, kemampuan Marketing, kemampuan ini juga harus di miliki oleh amil, untuk menunjang pencapaian target yang harus dilaksanakan. Dalam melaksanakan promosi untuk mencapai target Lembaga Nurul Hayat Surabaya sendiri strategi yang digunakan adalah strategi promosi above the line dan below the line.

\section{Pendistribusian dan Pendayagunaan}

Pengetahuan akan fiqih zakat penting untuk dimiliki oleh amil zakat bidang pendistribusian dan pendayagunaan, karena dana zakat tidak boleh diberikan kepada sembarang orang. Pihak-pihak yang diperbolehkan untuk menerima zakat atau pihak-pihak yang membutuhkan dalam sasaran zakat disebut sebagai mustahik, yang terdiri dari delapan asnaf, Bentuk pemahaman amil Nurul Hayat mengenai fiqih zakat diwujudkan dengan dilakukannya survey untuk mengetahui kondisi dari calon mustahik.

Praktik di Nurul Hayat bahwasanya amil telah memiliki kemampuan public speaking, pelaksanaan public speaking terlihat dari komunikasi yang dilakukan amil dengan calon mustahik. Komunikasi tersebut bertujuan mengajak calon mustahik untuk diberdayakan, dan mempromosikan program pendayagunaan. Komunikasi ini dilakukan dengan cara pendekatan personal yang dilakukan oleh amil, untuk memastikan bahwa calon mustahik bersedia dilakukan pemberdayaan dan dilaksanakan report kegiatan setiap akhir minggu dengan presentasi setiap amil didepan tim program. 
Kemampuan public speaking juga dapat dilihat dari pelatihan yang diikuti dan pengalaman dalam bekerja, sebagaimana teori Sutermeister menyatakan bahwa kemampuan berasal dari pengetahuan dan keterampilan. Menurut teori amil di Nurul Hayat Surabaya telah memiliki kemampuan public speaking, dilihat dari pelatihan yang diikuti dan pengalaman dalam bekerja, bahwa amil nurul hayat Surabaya telah mengikuti training untuk meningkatkan kemampuaanya.

\section{Profesionalisme Amil}

Amil pendistribusian sudah melaksanakan tanggung jawabnya sebagaimana amil, bentuk dari tanggung jawab tersebut adalah melaporkan perolahan dana zakat setiap hari yang dihimpun kepada admin penghimpunan zakat. Kemudian admin penghimpunan zakat melaporkan kepada manajer.

Profesesionalisme merupakan kecenderungan sikap, mental atau tindakan anggota dalam menjalankan tugas profesinya. Profesionalisme juga dapat diartikan sebagai komitmen seseorang atau anggota suatu profesi untuk menjalankan tugas dan fungsinya. Amil Nurul Hayat Surabaya memiliki komitmen untuk jujur, amanah dan mampu mencapai target yang telah ditentukan.

Profesionalisme juga dapat dilihat dari keinginan untuk meningkat kemampuan, Amil Nurul Hayat Surabaya berupaya untuk meningkatkan kemampuannya melalui belajar dan mengikuti pelatihan atau training, membaca buku dan sharing dengan teman dan amil lainnya.

\section{Pendistribusian dan Pendayagunaan}

Amil pendistribusian sudah melaksanakan tanggung jawabnya sebagaimana amil, bentuk dari tanggung jawab tersebut adalah melaporkan kegiatan pendayagunanaan dan pendistribusian melalui IT, jadi sudah ada program untuk melaporkan kegiatan pendayagunaan dan pendistribusian. Setiap amil yang melaksanakan pendistribusian dan pendayagunaan zakat, amil selalu melaporkan dalam sistem yang ada di NH.

Jika ditinjau dari teori amil Nurul Hayat telah memiliki sikap profesionalisme terlihat dari komitmen yang dimiliki setiap amil. Diantaranya : amil Nurul Hayat Surabaya berkomitmen untuk mendistribusikan zakat 
kepada yang berhak menerimanya untuk memastikan kesejahteraan yang merata dan komitmen untuk mencapai target.

Salah satu upaya lembaga dalam mendukung petugas zakat adalah meningkatkan kemampuan amil dan profesionalisme untuk menunjang kemajuan lembaga, perkembangan zaman yang dinamis, menuntut setiap lembaga untuk mengupgrade kemampuan para amil, untuk tetap mampu berdiri kokoh dan berdaya saing. Sebagaimana kemampuan menjadi faktor penentu keberhasilan dari departemen personalia untuk mempertahankan sumber daya manusia yang efektif.

Upaya Lembaga Amil Zakat Nurul Hayat Surabaya dalam meningkatkan kemampuan dan profesionalisme amil dalam pengelolaan dana zakat adalah melaksanakan evaluasi setiap bulan. Setiap manajer melakukan penilaian kemudian mengevaluasi setiap stafnya untuk mengetahui tingkat kemampuan dari setiap amil dalam melaksanakan targetnya. Begitupun dengan manajer pendistribusianbahwa ketika amil tidak ada progress untuk melaksanakan tugas dan tanggung jawab ketika sudah diberi training maka amil tersebut akan dicoaching.

Uapaya yang lain adalah pemberian training, Pelatihan yang dibutuhkan setiap divisi berbeda-beda, diantaranya: divisi penghimpunan zakat membutuhkan karyawan yang mampu dan profesional dibidangnya dengan memberikan training berupa seminar fiqih zakat, pelatihan public speaking dan ilmu marketing. Untuk pendayagunaan zakat diberikan training berupa input data mustahik yang akan disantuni, dan public speaking.

Upaya selanjutnya yang diberikan oleh lembaga untuk memaksimalkan kemampuan dan profesionalisme amil adalah adanya report penilaian per bulan yang dilakukan oleh tim manajer, kemudian di share ke anggota amil yang lainnya, untuk memberikan dorongan motivasi tersendiri dalam menyelesaikan tugas sebagai amil.

\section{Kesimpulan}

Amil zakat Nurul Hayat Surabaya telah memiliki kemampuan amil dalam pengelolaan zakat, terbukti dari pelatihan yang diikuti ,pengalaman pekerjaan setiap amil, target yang mampu dicapai, dan breafing yang dilaksanakan amil setiap pagi. Amil Nurul Hayat Surabaya juga telah memiliki profesionalisme dalam pengelolaan dana zakat yang mampu dihimpun dan didistribusikan. Profesionalisme tersebut terbukti dari sifat amanah yang 
Hanafi Adi Purwanto, Mengukur Kompetensi Amil Melalui Kemampuan...

ditunjukkan dengan pelaksanaan pelaporan amil dalam penghimpun dana zakat maupun mendistribusikan, dan dibuktikan dengan komitmen yang dimiliki setiap amil dalam melaksanakan tugas sebagai pengelola zakat.

\section{Daftar Pustaka}

Budiman, Tri Esti., Imam Firmansyah, “Efektivitas Pelatihan Public Speaking Terhadap Peningkatan Pengetahuan Tentang Komunikasi Pada Fasilitator Experience Learning (Outbound) PT Hucle Consulting". INTUISI Jurnal Psikologi Ilmiyah, 2 (1) 2012.

Creswell, John W. Research Design Pendekatan Kualitatif, Kuantitatif, dan Mixed. Yogyakarta : Pustaka Pelajar, 2010.

Fatmawati, Lusi. "Pengaruh Shariah Compliance, Transaparansi, Akuntabilitas dan Kompetensi Sumber Daya Manusia (SDM) Terhadap Pengelolaan Dana Zakat (Studi pada Organisasi Pengelola Zakat di Kabupaten Sukoharjo)". Skripsi, Institut Agama Islam Negeri Surakarta tahun 2017.

Fauziatunisa, Hanani. "Analisis Kemampuan Kerja, Coaching dan Kinerja Karyawan : Studi Kasus Pada Karyawan PT Sari Ater Hotel Dan Resort Subang". Jurnal Of Business Management Education, 3, (3) 2018.

Fujianti, Lailatul. "Pengauh Profesionalisme Terhadap Komitmen Organisasi Da Kepuasan Kerja Serta Dampaknya Terhadap Kinerja Akuntan Pendidik". Forum Bisnis Dan Keuagan 2 (1) 2012.

Hafidhuddin, Didin. Zakat dalam Perekonomian Modern. Jakarta : GEMA INSANI.2002.

Hariasih, Misti., Herlina Maya Kumala Sari., Totok Dwi Prasetyo, "Pengaruh Penilaian Prestasi Kerja, Kompetensi Karyawan dan Pengalaman Kerja terhadap Promosi Jabatan pada Lembaga Amil Zakat Nasional Nurul Hayat Surabaya". Jurnal Bisnis Manajemen dan Perbankan, 3 (2) 2017.

Ivancevich, John M. Perilaku dan Organisasi 1. Jakarta: ERLANGA, 2006.

Khasanah, Umrotul. Manajemen Zakat Modern. Malang: UIN MALIKI PRESS, 2010.

Kusuma, M. Yudistira. "Respon Pengurus Forum Organisasi Zakat terhadap Undang-Undang No. 23 Tahun 2011 tentang Pengelolaan Zakat", Skripsi UIN Jakarta (2013).

Limakrisna, Nandan., Wilhelmus Hary Susilo. Manajemen Pemasaran. Jakarta: Mitra Wacana Media, 2012.

Magkunegara, Anwar Prabu. Manajemen Sumber Daya Manusia Perusahaan. Badung : PT Rosdakarya, 2013. 
Mufraini, M. Arief. Akuntansi dan Manajemen Zakat. Jakarta : Kencana 2006.

Mufraini, M. Arief. Akuntansi Manajemen Zakat. Jakarta : Kencana Prenada Media Group. 2006.

Muhammad dan Ridwan Mas'ud. Zakat dan Kemiskinan. Yogyakarta : UII PRESS, 2005.

Nasim, Anim., Muhammad Rizqi Syahri Romdhon, "Pengaruh Transparansi Keuangan Zakat, Sikap Pengelola Zakat Terhadap Tingkat Kepercayaan Muzakki". Jurnal Riset Akuntansi dan Keuangan, 2 (2) 2014.

Pane, Irwani. "Analisis kemampuan Public Speaking anggota DPRD kota Makassar Masa Bakti 2009-2014". Jurnal Komunikasi KAREBA, 1 (1) 2011.

Rahman, Muhammad Abdul Malik. Pustaka Cerdas Zakat : 1001 Masalah dan Solusinya. Jakarta : Lintas Pustaka, 2003.

Sahroni, Oni. Figh Zakat Kontemporer. Depok: PT Raja Grafindo Persada, 2018.

Wibowo. Perilaku dalam Organisasi. Jakarta : Pt Raja Grafindo Persada, 2016. 